\title{
Competing Visions of Welfare in the Zaydi Community of Medieval South Arabia
}

\author{
Eirik Hovden \\ Introduction
}

This chapter addresses ways in which followers of the Zaydi Islamic sect in the highlands of early medieval Yemen (c. AD 900-1200) invoked and engaged in visions of welfare for their community. The visions of community were subject to strong tensions from various actors, and this chapter uses disagreements over "welfare" and the religious alms tax (zakāt) as lenses through which to study this dynamic situation of competing visions of spiritual community.

Although it has rarely been attempted to compare the phenomenon of hijras with European and Tibetan monasteries or similar institutions of learning in the medieval period, ${ }^{1}$ it seems clear that the study of hijras in Yemen and their inhabitants and their visions of community will benefit enormously from comparison. Comparing our terms and concepts against contrasting cases and theories allows us to achieve a better analytical distance to our study object. The concept of the hijra was central for Muslim visions of community, based on its reference to the act of the Prophet when he emigrated away from unjust rule and set up his own ideal Islamic community. ${ }^{2}$ More specifically, in medieval Zaydi Yemen, the hijra was at first an ideal and imagined "enclave" in which ideal religious life could be upheld and practised, including core activities such as transmission of learning, however, over the period under scrutiny, we also see the development of hijras into institutions arguably comparable to monasteries and gompas, a transition described by the historian and Islamologist Wilferd Madelung. ${ }^{3}$ This development will be discussed in this chapter, with a special focus on tensions and competing visions within the Zaydi community, especially related to welfare.

1 For such a comparison, see Kennedy, "The Ribāt in the Early Islamic World". The research for this article was funded by the Austrian Science Fund (FWF): F42 Visions of Community.

2 Montgomery, "Hidjra"; Madelung, "Has the Hijra Come to an End?".

3 Madelung, "The Origins".

(C) EIRIK HOVDEN, 2016 | DOI 10.1163/9789004315693_016

This is an open access chapter distributed under the terms of the Creative Commons Attribution-

Noncommercial-NoDerivatives 3.o Unported (CC-BY-NC-ND 3.o) License. 
Instead of focusing broadly on all aspects of hijras as "enclaves of learning", this chapter will focus on the role of "welfare" in visions of community invoked and contested by their members. One of the forms of welfare specifically scrutinized is the ideals, rules and practices related to the collection and distribution of the obligatory religious tithe called $z a k a \bar{t} t{ }^{4}$ but also other forms of welfare will be looked at. The word șalāh means "good", "proper" and "welfare" and recurs frequently in the sources from the period. The related word mașlaha and its plural, mașälih, can refer to the "interests of Islam" or "the common good". However, these two words are only some among many terms conveying meanings related to "welfare". Welfare can also be an etic, analytical concept that we can look for in the sources, also expressed through symbols and practices. "Welfare" may relate to sharing of food, clothing, housing, scholarships for students, paid positions for teachers etc., but it can also be the "welfare of the wider Muslim community". The principle of mașlaha (utility) and mașlaha ámma (common good, public interest) are well-known Islamic concepts, where the "Muslim community" is the ultimate frame of reference..$^{5}$ This can also lead to notions of public order, government and rule of law, ${ }^{6}$ however this would be too large an expansion to be useful for an analysis.

In this chapter, welfare, as an analytical tool in studying visions of community is deliberately kept open to ensure a dynamic and explorative reading of the sources, but the focus is kept on the terms șalăh and mașlaha. Through three cases we will try to see how members of "enclaves of learning" sought to organize the collection and distribution of wealth in a way that strengthened the enclave and the wider community they were part of and who they saw as included in their community and who were to be excluded. As we shall see, there were several competing visions on how, for example, religiously

4 Zakāt is one of the five pillars of Islam and thus a most central religious obligation. In medieval Zaydi Yemen, $z a k \bar{a}$ t generally meant paying ten per cent of normal agricultural output to one's religious authorities. Zakāt law is complicated and some simplifications are made here for clarity of argument. See Zysow, "Zakāt"; Madelung, "Land Ownership and Land Tax".

5 Zysow separates the notion of mașlaha into two: the philosophical principle of utility on the one hand, and the common good on the other, both being powerful arguments in Islamic law. Zysow, "Mașlaha". For discussions of mașlaha in medieval Zaydi law, see Hovden, "Flowers", Chapter 8: "Knowledge and Utility; Conclusions", 498-505. For an interesting study of related phenomena in the present, see Salvatore and LeVine, "Socio-Religious Movements", 29-56.

6 There are several academic works analysing such topics in Islamic literature or in "Islamic thought", a prominent example being Commanding Right and Forbidding Wrong in Islamic Thought by Michael Cook. He also has a chapter on Zaydis, including medieval Zaydism. Cook, Commanding Right. For medieval Zaydism see, ibid. 227-47, and Crone, God's rule, 99-109. 
legitimated taxes such as zakāt were to be collected and spent, and for which purposes. The visions invoked had often clear legal and economic consequences for those involved, and these visions were therefore also constantly contested and opposed. It is important to point out that welfare is more than just "economy" or "zakāt-law", words which may sound too disconnected from notions of community, spirituality, morality, and piety. The use of "welfare" as an analytical tool is an attempt to connect the economic and the religious/ spiritual level of our analysis.

The hijra is at the present an important institution in the highlands of Yemen. It is an enclave, usually a village, situated in an otherwise tribal context enjoying protection agreements with the surrounding tribes. ${ }^{7}$ The inhabitants of the hijra have a special religiously oriented identity and they engage in religious and scholarly activities. Usually, the inhabitants claim to be direct descendants from the Prophet in the male line, so-called sāda (sing. sayyid). These were mainly called Alids, or especially ashräf (sing. sharīf) in the medieval period. This latter term will be used in this chapter. Exceptions to these ashräf-dominated hijras were the Muțarrifi hijras in the medieval period, which we will come back to shortly below. ${ }^{8}$ Patrilineal genealogy (nasab) was and still is important in identity and self-definition for the ashrāf vis-a-vis the local tribal population, and they do not (ideally) intermarry with members of local tribes or low-status groups. ${ }^{9}$ At certain times in history, the hijras were important administrative centres and centres of support for the Zaydi imams (a combined religious and political leader for the Muslim community according to Zaydi doctrines). Yet for most of history hijras were rather semiindependent from any effective state-like polities and only loosely interconnected with each other, often through kinship ties and intellectual networks. The inhabitants were mainly sedentary farmers owning land in and around the hijra, thus not differing entirely from the surrounding local tribal population in terms of economic activities. A few individuals were travelling students and scholars specializing in Islamic learning. Some hijras were famous religious schools or centres, but few remained so for a longer period of time.

7 Tribes in Yemen are mainly sedentary farmers and tribal territory is a geographically defined area. There is a wide variation in the phenomenon of hijra in Yemen, which we cannot deal with here. For the most important historical overview from the Zaydi highlands, see Dresch, Tribes, 136-83. For the medieval period see Madelung, "Origins".

8 In the Qāsimi period (starting ca. 1650) and afterwards, we also see hijras with non-sayyid, so-called Quḍāh population, thus non-ashräf hijras were certainly not endemic only to the medieval period.

9 In recent times we know that sāda may marry tribal women (hypogamy), but not the other way around. 
The phenomenon of hijras in the highlands of Yemen sees much variation, an important topic, which cannot be fully treated in this chapter.

This chapter is only about the early medieval period (c. AD 900-1200) and thus the period of formation of both Zaydism and the hijras in Yemen. It is not about the late medieval period (c. 1300-1550) or the subsequent first Ottoman or Qasimi periods, where the development of the institution of hijras reached a more stable phase. Although the institution of hijra at a first glance shows remarkable stability over time, the political and religious context was quite unique in the early medieval period. For example, this formative and dynamic era saw the growth and decline of a strong local, popular, personal-merit/pietyoriented (and finally, "heretical") variant of Zaydism, the so-called Muțarrifiyya, including its final repression. The Zaydis were also in fierce conflict with local political dynasties, which had Isma'ili or Sunni leanings and creeds and in tension with local, tribal shaykhs and lords who constantly shifted religious affiliation according to their needs-being Sunni one day, Zaydi the other and Isma'ili next year. It was in this highly heterogeneous political landscape that the hijras appeared as institutions providing frames for engagement in religious learning and practice in the rural areas of the highlands of Yemen. In the following, we will chronologically look more closely at three distinct cases, roughly from three subsequent centuries, starting from c. AD 9oo. The cases show how different visions of community can be seen within the Zaydi sect, partly related to the formation and the development of the institution of the hijra. As a final note on the concept of hijra it must also be pointed out that the term itself may have merged with the local tribal (and pre-Islamic) concept of hajar, meaning "town" or "sanctuary". In modern usage the term tahjir means to give the status of sanctuary to a place, a person or a family. The term itself was thus not only an Islamic innovation introduced to Yemen in the early medieval period; the Islamic and the tribal meanings are partly overlapping. ${ }^{10}$

\section{The woth Century AD}

In AD 897, Yahyā b. al-Ḥusayn settled with his family and a few followers at al-Ghayl ${ }^{11}$ near the (old) town of Sa'da. He came from a "noble" (ashrāf) family from near Medina, meaning that he belonged to the direct descendants of the Prophet. His family upheld a Zaydi (Shi'a-related) version of Islam, claiming that the Abbasids were not the rightful rulers of the umma, but rather, that the

10 This is clarified and discussed by Puin, "The Yemeni Hijrah Concept of Tribal Protection", and Serjeant, "Șan'ā' the protected Hijra".

11

The location of today's town of Sa'da. 
leadership of the Muslim community should have stayed within the direct male descendants of the (daughter of the) Prophet, the so-called ahl al-bayt or ashrāf. He took the imamic title "al-Hādī ilā al-Haqq" (hereafter al-Hādī).. ${ }^{12}$

AD 897 marks the beginning of Zaydism in Yemen. For the rural tribal areas in the highlands, this time is not only a phase where one can see the seed of Zaydism and its growth through certain networks, but also a new phase of Islamization in general. ${ }^{13}$ While that term can mean many different things depending on which phenomenon one aims to look at, I am referring to the use of the Islamic intellectual tradition, and more specifically the use of this tradition by local elites in their own political projects and the use of this tradition in attempts to build new non-tribal polities and visions of community based on Islamic discourse and concepts. In this perspective, Islam was at this time increasingly being used by certain actors in order to create new alliances, new polities, new discourses, and new visions of community. Most of the local contemporary culture in the highlands, at least outside major cities like Sanaa, centred around tribal visions of community—being members of tribes, sharing obligations in protection of common land and common interests, having ties to one's tribe and to other neighbouring tribes and regulating all this with tribal custom. The tribal vision of community offered an egalitarian brotherhood ideal, where all men could be part of a just and proud community—ideally, of course. Some would say there was no need for Islam in this situation. ${ }^{14}$

The new phase of Islamization increasingly seen at the end of the 9th century was characterized by the appearance of certain new forms of charismatic

12 For information about al-Hādī and his context see the biography written by his secretary 'Alī b. Muhammad al-'Alawī, Sïrat al-Hādī. For analysis of this period see: Van Arendonk, De Opkomst; Gochenour, "The Penetration"; Heiss, "Tribale Selbstorganisation". The ahl al-bayt is not entirely the same as the term ashräf, but for the sake of simplicity of argument I will not go into this here. In the beginning of the period described here, we see the term 'Alawis ('Alids) being used, but for most of the early medieval period the common term is ashräf. In later periods and today they are called sāda, sing. sayyid. See Zayd, Tayyārät, 146. See also the comparative analysis by Heiss and Hovden to Heydemann in this volume.

13 See for example Gochenour, "Towards a Sociology of the Islamisation of Yemen", and "The Penetration".

14 This can be seen in the famous intellectual al-Hamdānī's works as treated by Daniel Mahoney in this book. In al-Hamdānì's description of the South Arabian tribal society, although he does not oppose Islam directly, he indirectly describes a society where the Zaydi ashräf and other Islamic sects have no importance. 
leaders basing their ideologies exclusively ${ }^{15}$ on Islam, claiming to be the interpreters, executors and representatives of religion. The political momentum that followed some of these charismatic leaders had a large impact on the Yemeni highlands for some short periods, while for most of the time their power was confined to very limited networks and geographically small pockets. These religious leaders also had to compete with other religious leaders from the same sect or other sects, and with powerful local tribal lords (salāțin, $m u l \bar{u} k$ ). We also almost only get to hear about their success stories, since the sources we have from this time are mainly biographies and chronicles written by their secretaries or court scholars. The timing of these new activities is partly related to the general activities of the (proto-)Shi'a elsewhere in the Islamic world and we certainly see an influx of ashräf/sāda/'alid families into South Arabia at this time.

There were several such Shi'a-oriented groups at this time in opposition to the Abbasids in Baghdad, mostly Zaydi or Isma'ili. One of the fundamental doctrines of Zaydism is that in the presence of an unjust ruler, withdrawing from loyalty and "going out" (khurüj) and outwardly declaring political opposition is not only allowed, but a religious obligation, and further, that one should follow the righteous leader of the Muslim community, the imam. The imam was to be chosen ${ }^{16}$ among the Ahl al-Bayt. To leave unjust and oppressive rule $(z \mathrm{ulm})$ and to follow a rightful imam was called an act of hijra, in analogy to the act of the Prophet as he left his home town of Mecca where his own tribe was opposing him, setting up his new base of Islamic rule in Medina with his hijra followers (muhäjirūn) and helpers (anșār) around him. At the time when al-Hādī arrived in Yemen the term hijra could thus also refer to the concept of creating a new, righteous religious enclave in an otherwise tribal context characterized partly by the lack of religion, and partly by the diffusion of "erroneous" forms of Islam.

Setting up his new enclave in Sa'da, in the very north of today's Yemen, al-Hādī was still close to his Zaydi/Ashrāf network elsewhere in the Hijaz and in other parts of the Abbasid Empire. Yemen consisted of relatively fertile areas where agricultural surplus made taxation profitable for those who could claim political and military power, yet at the same time, he was far enough away from

15 Actually, when reading the sources in a less ideological light, we can easily see that these charismatic rulers had to compromise in several values in order to be accepted in the local, tribal community.

16 The theories of bay'a: call of allegiance ( $\left.d a^{c} w a\right)$, which should be met with a pledge of loyalty $\left(\right.$ bay $\left.^{\prime} a\right)$. For a detailed history of the developments of these doctrines, see Madelung, Der Imam al-Q̄āsim ibn Ibrāhìm. 
the Abbasid Empire centred on Baghdad. He could utilize the relative lack of centralized rule in Yemen and rather cooperate with certain local tribes and tribal elites. He set up his little "enclave"17 in tribal territory by invoking protection as a holy man who could perform religious services and mediate in tribal conflicts. His high status of learning was an important part of his self-legitimation. He called himself a Zaydi imam, taking the title al-Hādī ilā al-Haqq, "The guide to the truth", claiming to be the leader of the Muslim community in religion, law, learning and in political matters. In little more than ten years he managed to unify several of the local tribes and to make them pay religious taxes and military duties to him.

Al-Hādì's secretary 'Alī b. Muhammad al-'Abbāsī al-'Alawī describes the political career and success of al-Hādī in the biography Sìrat al-Hādī.18 However, he also describes the resistance al-Hādì met from various local tribal leaders and from the competing Isma'ili sect, which had a strong presence in the areas west of Sanaa. Al-Hādī was also joined by fellow ashrāf from elsewhere in the Muslim world, and in the end he commanded a substantial network of allies. His ideal vision of community was to introduce and implement an Islamic society based on the canon of Islamic doctrine and law formulated by himself, his Zaydi grandfather al-Qāsim bin Ibrāhīm al-Rassī, and other scholars of the Zaydi tradition. At that time, Islamic law was still under active development, but there was already a vast intellectual tradition that could easily be tapped into, also in doctrinal and legal matters regarding the organization of welfare. With the help of a small group of Islamic scholars and intellectuals, Al-Hādī could therefore set up a vision including a system of religiously sanctioned taxation and redistribution to the local poor and payments to his own followers, which in its ideal form would undermine a tribal society where each tribe or lord ruled their own areas independently. In its not-so-ideal form, the tribal elites did not feel threatened as long as they were allowed to keep their privileges and remain the tie between the imam and the local tribe. Some tribal leaders were obviously satisfied with performing military services in al-Hādī's political project, receiving booty and positions as governors in return. Al-Hādī for his part, was very clear that he did not want to demand more taxes than the Quran and the Sunna (the collected and authorized sayings and deeds of the Prophet) stipulated; he had to appear absolute in his role as a religiously sanctioned leader. ${ }^{19}$

17 This is an example where I think "enclave of religion" or "enclave of religious practice" would fit better than "enclave of learning". Cf. Fermer in this volume on the various designations for monasteries in Tibet.

18 'Alī b. Muḥammad al-'Alawī, Sìrat al-Hādì ìlā al-Haqq; Van Arendonk, De Opkomst.

19 See also: Gochenour, "The Penetration", 84. 
It would be too much to go into detail here about al-Hādī's ideals and rules concerning taxation and $z a k \bar{a} t$, however we shall mention a bare minimum: Arabia was theoretically land that submitted voluntarily to Islam, therefore the land remained "private property" (contrary to most other parts of the Islamic world were land belonged to the umma and was rented out by the commander of the faithful). ${ }^{20}$ Taxation legitimized by Islamic law was therefore limited to a maximum of ten per cent ('ushr) of agricultural output. ${ }^{21}$ This tax, called $z a k a \bar{t}$, is one of the five pillars of Islam and conveys the notion of "purification". Other terms interchangeably used were 'ushr (lit. "tithe"), jibāya, huqūq, wājibāt, amwāl Allāh, and kharāj. There was a lower yearly limit of five $a w s a q^{22}$ or 200 dirham qifla ${ }^{23}$ of each single type of crop, below which, zakāt would not have to be paid. It seems that it was very important for al-Hādī, who was also presenting himself as a learned Islamic scholar of the ultimate level, to show that he knew the details of law and followed it without exception. It was part of his image that when he conquered an area, or offered his government, he claimed that he would abolish the high, uncanonical taxes and only take what is stipulated in the religiously sanctioned Islamic law.

We find al-Hādî's theories rather elaborated in his figh works (Islamic legal theory), but also in more practical form; for example in a letter to his governors telling how they should behave: they should teach the local population about Islam and administer the collection and spending of taxes. ${ }^{24}$ We know little

20 This is according to al-Hādī himself. Al-Ahkām, 1:171. It is also a common view of later Zaydi imams. Kharāj was something very different in the central Islamic lands where land was owned by the umma or the state and rented out for a rent called kharāj, in effect, something that could be seen as a normal tax and much higher than 10 per cent.

21 There are many exceptions to this and details in the zakāt law, but for sake of clarity of argument, we shall use the 10 per cent estimate here.

22 Wasaq is a grain volume measurement according to al-Hādī equal to 60 șā́, but he does not indicate what this means in the local context in Yemen in value or weight, except that the sum 200 dirham qifla is usually mentioned along with the nișāb in later Zaydi fiqh texts. Yahyyā b. al-Ḥusayn, Kitāb al-Aḥkām, 1:181. Madelung calls wasaq "a camel load". Madelung, "Land Ownership and Land Tax", 190. The niṣāb is not supposed to be measured in weight because it is a measure of volume, but if it is converted the weight and value depends on the quality of the grain. Zyzow gives the estimate of ca. 600 kilos of grain. Zysow, "Zakāt".

23 The dirham may be around $3 \mathrm{~g}$. But since the figure of 200 dirham is repeated in several later Zaydi figh works when the actual value could not be have been stable, it is difficult to see that this exact figure was taken literally. Five awsaq of grain was not always worth 200 dirham, as grain price is not stable over time, but the jurists still repeated this ratio, and it is simply taken from the Sunna in direct wording and cannot be changed.

Van Arendonk, De Opkomst, 113-58. An edition of the letter is given on page 292-94. 
about the extent to which this was actually carried out, since the author of our source just re-presents al-Hādì's order to his governors. Of course, we must assume that al-Hādì's network and followers got their share of the resources in the form of positions as army leaders, judges, teachers and governors, and he indeed allowed for this. ${ }^{25}$ Contrary to many other Islamic historical contexts, ${ }^{26}$ zakāt in the view of al-Hādī was not a voluntary act of piety, it was the main bulk of his legitimate tax income and it was to be compulsory for Zaydis. Al-Hādī also explicitly prohibited any other person from collecting and distributing the $z a k \bar{a} t$ other than he himself, the Commander of the faithful. ${ }^{27}$

Ideally, the local poor were to receive a quarter of the locally collected $z a k \bar{a} t^{28}$ (two of the eight recipient categories mentioned in the Quran are the poor; the fuqarä and the masākin ${ }^{29}$ thus a quarter), and the governors of the various districts were ordered to keep lists of the local poor. Al-Hādī also stated that if the Muslims (i.e. the umma, the community) had what they needed, then he would give a half of the $z a k \bar{a} t$ income to the poor, or even all of it. ${ }^{30}$ However, we know that he quickly had to compromise on his ideal way of

25 Al-Hādī said that the governors could divert funds directly from the tax income in order to cover their expenses for eating, drinking, clothing, transport (riding), servants and housing, "according to the norm" (bil-ma'rüf) and the imam's approval. Yahyā b. al-Ḥusayn, Kitāb al-Aḥkām, 1:174.

26 Zysow writes that by the year 1100 it was no longer common for zakāt to be organized by the state in the Muslim world. Zysow, "Zakāt". It seems that Zaydi Yemen must have been very different, at least in the views of the Zaydi elites themselves, where zakät-related arguments were at the centre of visions of welfare.

27 Yahyā b. al-Husayn, Kitāb al-Ahkām, 1:192. The zakāt seems to have a similar status for all the later Yemeni Zaydi imams in the medieval period. While most other Islamic regimes could take land rent, the zakāt was the only Islamic tax available to the Zaydi imams in South Arabia.

28 The quarter to be distributed to the poor quoted after the letter itself: Madelung, "Land Ownership and Land Tax", 190-91. Van Arendonk, De Opkomst, 125 and 294. Al-'Abbāsī al-'Alawī, Sìrat al-Hādī, 48.

29 The fuqarä' are those who only have a house, a servant and clothes and the masākin are those in need. Yahȳā b. al-Husayn, Kitāb al-Aḥkām, 195.

$30 \quad$ Al-Hādī committed to increase this share to a half or even all of it when the zakāt was not needed by community ("the Muslims"!) in the future: "For everything called șadaqa is to be set aside a quarter for the poor (masākin). If God makes the situation better for the Muslims [in the future] we will set aside a half for the poor. If the Muslims become rich [and do not need it], we will give everything to the poor". Al-'Abbāsī al-Alawī, Sīrat $a l-H a \bar{d} d \bar{\imath}, 48$. Madelung, "Land Ownership and Land Tax", 48. 
spending the funds. One of his most prominent students, Aḥmad b. Mūsā al-Ṭabarī, asked him directly why he had stopped distributing funds to the local poor, and al-Hādī answered: ${ }^{31}$

We [I, the Imam] made this [decision] regarding the zakāt (al-acshär): In some cases we distribute it [to the poor] and in some cases not. And in making that decision, we look for the welfare ${ }^{32}$ (șalāhn) of Islam, if we can identify it and if it becomes clear for us, and if we can know it. Only when Islam and the Muslims get what they need, and our [the imam's] need for this zakāt-income diminishes, then can we divide it according to the eight [Quranic] categories of recipients, or, whoever we can find identical to these. However, if the Muslims and Islam are in need of it [the $z a k a \bar{t}$-income], we would bypass them [the local poor], according to what we think and know would be more important (arjah) in each specific case.

And that specific case is that the welfare of the community (al-dār) cannot be upheld (lä tuṣlah) without armies (juyūsh) and loyal followers (anșār), horses and men. Community cannot be upheld and kept together (là tujtumía) without funding.

So therefore we have decided (nazarnā) that because in these lands that we are in there are no other [legitimate taxes] than this zakāt income, and because of the needs for support of my followers (the muhäjirün and the anșār), and also because the needs for defence when facing death and devastation by the help of this insignificant income [which is so low in the first place]. If we had to return these funds to the poor and divide them on the other recipient categories, then the standby soldiers would disappear and the community (al-jamā'a) would disintegrate (tabaddada), the muhäjirūn would dissipate and the Muslims would be degraded, calamity would take place, chaos (fitna) would be complete,

31 At the end of his career, al-Hādī is accused of using all of the zakāt for war. See Madelung, "Land Ownership and Land Tax", 191, 207 n. 8. Madelung refers to van Arendonk 260 (sic, $237-38$ is correct). Arendonk, De Opkomst, $237-38$.

32 One could also translate this as "interest", utility, but here the word is saläh and not mașlaḥa and it is "for" someone; for Islam. "Interest" is close in meaning to "welfare" when the interest is for the good of something/someone, as already mentioned above, referring to Zysow, "The Obligation". "Welfare", just as "good" is a powerful word, not possible to fully capture in a translation, just as "șalāḥ" is an also self-legitimizing term, and when used in religious discourse it a powerful tool, invoking the totality of religion, and at the same time it is used in a very specific legal argument. 
the land would not be controlled, and none of the believers would see welfare (wa-lam yușliḥ ahad min al-ubbād). ${ }^{33}$

And so al-Hādī goes on, elaborating vividly and in elegant style, partly in rhyme, about the misfortune that would affect all parts of the Muslim community if chaos and war is not fought off. Following, he likewise describes how the community will benefit from wise spending of the taxes: the merchants can then trade safely and the farmers can again farm and income and prosperity will come back, and, in the end, the poor will also benefit from this decision. The decision to not divert funds to the poor, but rather to spend them on war and on government was for the welfare (șaläh) of the community. The reins of this decision were to be held by the imam himself, and he was to delegate power to regional governors in a top-down system. Al-Hādì's community is a community where the imam is at the absolute centre and at the top of the hierarchy, in this specific argument, because it would be for the best of the community.

Another of the compromises al-Hādī had to make relates to the concept of the enclave. He did not demand that his version of Islamic law had to be fully implemented in all areas, as long as the basics were followed, like prohibiting extramarital sex, or wine-drinking. However, among his followers, both locals and of ashrä $f$ descent, a much more ideal culture and conduct developed, creating a strong feeling of a community based on ideals and practices of (Zaydi) religious purity, in an elitist network centred around the leader. One can imagine the difference between the Zaydi elites and the tribes using different identity markers and discourses, one Islamic and the other tribal, while the tribal elites somehow fall in between in certain aspects. Al-Hādī did not mark out one clearly geographically defined "enclave" with clear borders around it, but rather established multiple smaller centres, by appointing governors and scholars to be judges and to teach about Islam and to administer taxes in a network of nodes in a political and geographical landscape. Al-Hādī himself travelled around and stayed in these places, like an itinerary emperor of medieval Europe, even though his main base was at al-Ghayl just outside the town of Sa'da. It is clear that the vision of community that al-Hādì claimed and invoked contained welfare for the local poor and for other "Islamic" interests, including the material infrastructure needed for activities related to (Zaydi) learning. The "enclaves of learning" in this very first century of Zaydism in Yemen were more like administrative centres where religion and learning also

33 Yahyyā b. al-Ḥusayn, al-Majmū'a al-Fākhira, 670-74. Another translation of this text is given in Stookey, Yemen, 89-90. 
had an important place, as the leading members of the sect were both religious scholars and administrators loyal to the same person and project. Al-Hādī's "enclave", hijra, in singular, was an ideological ideal of some sort, however, situated and spatially distributed in certain centres chosen because they were already important market towns and situated near towns with important seats of regional elites. These places were not called hijras (in plural) at this time, only later (from c. 1070-1100) were they called so. Rather, at al-Hādì's time, a hijra was the act of leaving the lands of an unjust ruler (such as Sunni Abbasid-controlled lands) and following the rightful leader in his quest, joining his community. ${ }^{34}$

These centres were highly dependent on those few ashräf families who remained in Yemen after al-Hādīs death in AD 911 and the following rule of his two sons. Their family dynasty almost collapsed when the last son died in AD 934. The remaining Hādawi family saw much internal strife and in around AD 950, we are talking about only a small handful of Zaydi centres; Sa'da being perhaps the only notable one. These centres were not called hijras at this time, but perhaps we could still see these centres as "enclaves of learning" when we imagine the activities, especially related to learning taking place there.

\section{The nith Century}

The 11th century saw a relatively weak, disunited and unorganized Zaydi movement. The tribal lords were powerful, and from the $1040 \mathrm{~s}^{35}$ a strong Isma'ili charismatic and military leader by the name of 'Alī b. Muhammad al-Ṣulayḥi took large parts of the highlands starting from the mountains west of Sanaa. Further north, in the areas around al-Ahnumm and near today's Khamir, the descendants of the Imam al-Manșūr al-Qāsim (al-Tyānī) $)^{36}$ set up an enclave, explicitly called a hijra, in the impressive mountain fortress of Shihāra, allying themselves with parts of the Hamdān tribes. This is the first time we see the term hijra referring to a specific place rather than an act or an abstract religious concept. ${ }^{37}$ One source tells us that this hijra had almost 600 houses and 764 pupils in the school there, of which 40 were ashrāf..$^{38}$ Zakāt was still highly

34 Madelung, "The Origins".

35 The exact year is debated; see Gochenour, "The Penetration", 310-16.

36 The so-called "Husayniyya" or "Qāsimiyya", "al-Ashrāf al-Qāsimiyyūn".

37 Madelung, "The Origins", 29.

38 Mufarrih b. Aḥmad al-Rabāī, Sìrat al-amīrayn, 196-97. Descriptions of Shihāra is given in ibid., 152-53; Madelung, "Al-Hamdānīs Description of Northern Yemen", 137. 
important for the viability of this small polity in securing payments for soldier and followers.

In one biography describing the acts of the leaders around the $1070 \mathrm{~s}^{39}$ we are presented with a critical question: "Is it really legal to take more taxes than the canonical zakāt?" The answer is a short treatise justifying taking not only a tenth, but even nine tenths if it was necessary to fight the Isma'ilis. ${ }^{40}$ These were times of war and the costs for war (jihād) against the Isma'ilis were higher than the income from the normal zakāt. The same leaders also explicitly point out that zakät is a religious duty, and if it is not paid, one's prayers will not be accepted by God. ${ }^{41}$ Paying zakät was not only showing loyalty to the only true religion and its representatives, it was simply an act of declaring and renewing one's political loyalty. Zakāt was in effect just one concept among many used to fund and legitimate warfare, where notions of safety, welfare, and the survival of the community was mixed together in a populist political discourse and blurred, rather than upholding a strict religious/legal definition of zakāt. The concept of jihād is closely linked to zakāt in this period in that both are obligations owed to the imam, legitimized by the need to secure and protect the welfare of the religion and community. To summarize so far: at the end of the 11th century the political elite of the Zaydis was divided into (at least ${ }^{42}$ ) two regional powers, one represented by the Qāsimī Ashräf in Shihāra and western Hāshid, while Sa'da and its immediate surroundings remained under the control of the Hādawi family, who in this period were at a slightly safer distance from the Isma'ilis, who held the wider Sanaa area. These two Zaydi dynasties were both similar in that they claimed that the central imamic authority should control the "welfare" of the community, although the Hādawīs were quite weak at this time. The Qāsimi Ashräf were perhaps even more extreme in their focus on war, especially if it really is true that they took as much as nine tenths of the harvest from the local farmers and tribes. ${ }^{43}$

The 11th century also saw the start and initial growth of the Muțarrifiyya, a populist movement focusing on personal piety, the love for God, knowledge

39 Al-Rabaīì, Sìrat al-amìrayn, 84.

40 Al-Raba'ì, Sirat al-amìrayn, 84-85.

41 Al-Raba'ī, Sìrat al-amìrayn, 289.

42 What later became the Banū Hamza started their activity in the 11th century, and their power base seems to have been in the eastern Hāashid and Bakīl areas.

43 This is legitimated by the al-Sharîf al-Fādil according to his secretary Mufarrih al-Rabā̄ī. Al-Raba'ī, Sìrat al-amīrayn, 84. Later, Musallam al-Lahjī criticizes the two Amīrs for this practice, especially in the lands near the front line such as the areas west of Sanaa. Al-Lahjīi, "Akhbār al-Zaydiyya", 319. 
and worship. The Mutarrifiyya started a local Zaydi alternative to the imamcentred vision of community. ${ }^{44}$ They wanted to establish their own system and to collect and distribute their own taxes, in much smaller face-to-face networks and communities. In addition to Islamic taxes they also encouraged personal generosity and support from wealthy individuals to the other sect members. However, in terms of doctrine, theology, and law, they claimed to be orthodox Zaydis and they called themselves "the Zaydis", (al-Zaydiyya). In the beginning they operated in a rather unorganized way seeking patronage from local lords with Zaydi leanings, especially in the Bawn area, which was a borderland between the Isma'ilis in the south and the two smaller Zaydi polities in the north. Later, they were also allowed to partly operate inside nominally Isma'ili territory, probably because of their apolitical profile in the beginning. Thus there were no powerful Zaydi imams who could "discipline" them, and the few imams who tried to claim the imamate needed their support. To conclude so far: the ashrāf and the Hādawi and Qāsimi dynasties did not produce strong imams in this period, and a bottom-up movement grew on the basis of the same Zaydi intellectual tradition, namely the Muțarrifiyya.

In the latter half of this century the Isma'ilis slowly lose their grip, leaving more room for institutionalization of the Mutarrifi hijras, especially in the areas west of Sanaa, from the Bawn in the north to Banū Shihāb in the south. The capital of the Isma'ilis is moved to Dhü Jibla near Ibb and the Sanaa area was held by the client dynasty called the Hatimids. The areas west of Sanaa where the Mutarrifiyya could now operate were densely settled rich agricultural areas with several important lords/elite-tribes. We do not know much about how the Muțarrifiyya balanced their vision of community with the existing tribal/feudal structures, but many of the local elites in these areas are presented as sect members and patrons at the same time. If the Mutarrifiyya really had collected the full amount of zakāt, would they not have become more powerful in politics? The Mutarrifiyya does not seem to have had ambitions to compete for political authority in a military sense. We simply do not know enough about their internal organization, coordination, and political ambitions, but we do know that they founded several hijras in their core areas in this period. ${ }^{45}$

Much of what we know about the Mutarrifiyya comes from the historiographical/biographical work ${ }^{46}$ by the Muțarrifi scholar Musallam al-Lahji

\footnotetext{
44 An article about the start of the Muțarrifiyya is being prepared by Johann Heiss and Eirik Hovden.

45 For the Muțarrifiyya in general, see Zayd, Tayyārāt; Madelung, "Muțarrifiyya".

46 Al-Lahjī, "Akhbār al-Zaydiyya".
} 
(d. c. 1150). He describes study circles as being common and that towards the end of this century they became increasingly institutionalized. Sometimes they met regularly during the grape harvest (in the season called khariff) ${ }^{47}$ Some lived together in small villages, emphasizing prayer and solitude, others in villages where they focused on intellectual interaction. They called these villages or centres for hijras. The Mutarrifis seem not to have challenged the political authority directly, even though they were of course against Isma'ili overrule in doctrinal and theological matters. The Mutarrifiyya did much to further spread Zaydism in the highlands west and south of Sanaa, where the Zaydi ashrāf previously had little influence. ${ }^{48}$

The vision of community that the Muțarrifis propagated, as least seen through the eyes of al-Lahjī, around 1140, was one where love of God was the motivation to share one's wealth and knowledge with other adherents in the sect. Obvious outsiders were the Isma'ilis. But at the time when al-Lahjī writes the history of the sect he also indirectly attacks the imam-centred vision of Zaydi community and introduces a series of other ideals for welfare management: pious individuals could manage welfare on the lowest possible level without a centralizing structure. A simple example is the biography of a person, probably living at the very end of the 1th century, possibly the beginning of the 12th. At the first glance it is not very impressive compared to the biographies of Zaydi scholars and imams, but underlying is a very different ideal of how zakāt could be collected and distributed locally:

\section{Al-Ṣalūlì}

He is 'Abd Allāh b. — ${ }^{49}$ al-'Ashbī, ${ }^{50}$ known as al-Ṣalūlì. He is among the earlier ones described in his generation (tabaqa). He was among the representatives of good, having qualities like diligence, companionship, polite speech, a humble appearance, love for being useful for the Muslims (naf'al-muslimin) and being a supporter of religion (al-ma'üna fíal-dìn). 'Ulyān b. Ibrāhīm, rahimahu Allāh, told me: People used to call upon 'Abd Allāh al-Ṣalūlī to collect their zakāt and to distribute it within their local community (wa-tafríqiha fi ahlihā), and he [al-Ṣalūīi] used to encourage them in that. He only approved of this [procedure] if every man had submitted his zakät to him. ${ }^{51}$ If he saw a poor believer deserving that [charity

\footnotetext{
47 See Al-Lahjjī, "Akhbār al-Zaydiyya", 30-32.

48 Gochenour, "The Penetration", 200.

49 Open space in the manuscript.

50 Vocalization uncertain.

$5^{1}$ This sentence is not entirely clear.
} 
from the $z a k \bar{a} t]$, and he approved of him [being a recipient], then he would give to him and give the rest back to them [the local community]. It is said about him [al-Ṣalūlī], related to this, that he said: "I would prefer that every believer could enjoy from it [the $z a k \bar{a} t$ ] what God has defined; I fear that people (al-qawm) will distribute it [the zakāt] to recipients outside the local community ( $f \grave{\imath}$ ghayr ahlihā), among God's enemies. If I should do what you asked me to do, I would have liked to support those

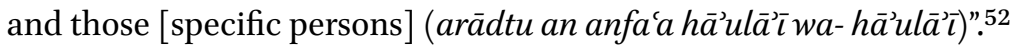

The idea of spending the welfare locally and on local poor where the effect can be easily seen and recognized by the givers is indeed a powerful one. The Muțarrifis did not oppose al-Hādī's theories on the imamate; they themselves claimed to be orthodox Zaydis following al-Hādī. But they opposed contemporary individual imam-pretenders, saying that they did not have enough personal quality $(f a d l)$ to be accepted as imams, since the imam should be the best of the believers in his time. And following al-Hādì's rules, if there is no imam present, the $z a k \bar{a} t$ is still an obligation and should still be collected and distributed locally. ${ }^{53}$ There is no space here to present and analyse similar narratives written by al-Lahjī, but there are many that emphasize the ideal of sharing meals, hosting fellow sect members, and behaving generously, in addition to mentions of local usage of the zakāt (and khums). ${ }^{54}$ For al-Lahjī, the "community" is made up of pious individuals ("Muslims" and "Zaydis") who come together and share according to the ideals of Islam, partly specified and codified by Zaydi-Hādawi Islamic law. Documenting personal quality $(f a d l)$ of sect members is important for him, be they of high or low status. War and political hegemony are not explicitly given priority, although stated implicitly only; the Zaydi community could be built locally without an imam.

\section{The 12th Century}

This is the century when the Mutarrifiyya became more institutionalized. Before AD 1100 they existed in more loosely organized networks with only a few important permanent places, like the school Muțarrif b. Shihāb established in

52 Al-Lahjī, "Akhbār al-Zaydiyya", 248. It is difficult to date the content of this story, but it seems like it must have been around 1100, at least some time before al-Lahjī himself.

53 Yaḥyā b. al-Ḥusayn, Kitāb al-Aḥkām, 1:201.

54 For similar reflections on the importance of khums, see for example al-Lahjīi, "Akhbār alZaydiyya", 6. 
Șinā' outside Sanaa, and the town of Madar $45 \mathrm{~km}$ north of Sanaa, where many adherents lived. Some time around AD 1100, Hijrat Waqash was established $25 \mathrm{~km}$ south-west of Sanaa. Several other hijras were also established, although few of them remained stable institutions independent of the founding teacher living there. Wilferd Madelung and David Thomas Gochenour provide lists of these hijras, which depending on the definition, give something like 20 hijras. ${ }^{55}$ The areas in the north were still more or less under control of the Hãdawi and Qāsimi ashräf, but from the Bawn southwards, south through al-Mașānic and Ḥadūur, to Banū Shihāb and even further south, the Muțarrifiyya grew in strength and towards the end of the century they became a political factor in these territories. What was special about the largest of these hijras, such as Waqash, was that they were institutions of their own, arguably calling for comparison with European or Tibetan monasteries. Earlier, transmission of learning had taken place in someone's private reception room or in various public places. Now the hijras became stable meeting places where travelling students and teachers could stay. The sources do not say much about how these hijras differed from normal villages and to what extent "normal" inhabitants lived there as well. Waqash became the main centre for the Mutarrifiyya and is perhaps therefore not representative of hijras in general. However, it must have been well known and perhaps been seen as some sort of ideal for other hijras. In one of the biographies of al-Lahji we can read about the role that a man by the name of Ibn Rifād (d. 1120 $)^{56}$ had in the management of the welfare in Hijrat Waqash:

And when he [Ibn Rifād] moved to Waqash, he became one of its most important leaders there. He was in charge of [the services for] guests (al-dayf) and strangers (al-gharīb) and those who had needs (dhawi $a l-h \overline{a j a}$ ) and [he had the role of] being an inspector (al-nazar) in matters regarding [the hosting of] travelling representatives (wäfid) and students of the Islamic sciences (mutacallimin) and the overseeing of the welfare (șalāh) of its [hijratwaqash's] mosques and its ritual baths (mațāhir) and its reception rooms (majālis) and other welfare ${ }^{57}$ related to Islam there (wa-sāir mașālih al-Islām bihā). ${ }^{58}$

55 Gochenour, “The Penetration", 172-73; Madelung, "The Origins”, 32-37.

56 Al-Lahjī, "Akhbār al-Zaydiyya", 253.

57 A more conventional translation of mașālih would perhaps be "interests" or "public interest" as mentioned above, or even "the community property" (al-mașālih), but here, it is clear from the context that what is meant is welfare institutions for people in the hijra, which at the same time are conflated with "Islam". 
Al-Lahjī studied in Waqash in the year $1116-17^{59}$ and would himself have known the institutions of the hjira very well. These services imply that there were buildings and food, which had to be supplied for the users of the hijra. The term "inspector" (näzir) is the same as later used for the manager or guardian of an endowment or foundation, although we do not have concrete textual evidence that these services were paid by endowments (waqf, pl. awqāf) belonging to the hijra at the beginning of this century. That mosques could have endowments, however, must have been normal already at this time and the Mutarrifiyya may have managed or overseen local endowments, for example for mosques in their region. ${ }^{60}$ Note how welfare, in the translation above, is something that is to be provided for the inhabitants and other users of the hijra, something again related to "Islam". These values are conflated into one.

For the Mutarrifis, visions of welfare for their community were not a matter of securing funding for war and government. The welfare they provided for the local population, and for the network of sect members in the hijras and elsewhere, must still have contributed to the consolidation of their feeling of community. The welfare facilitated the intellectual activities and activities related to learning by providing food and housing for those who wanted to live a life devoted to learning and religious practice. How this welfare was controlled and managed is a question that needs more research. One could hypothesize that in the mature phase of the Mutarrifiyya, in major hijras like Waqash, there must have been fault lines and discussions over who should get access to the welfare and the resources. We do not know to what extent some of these hijras pressed the local population for zakāt and the views of the power that these hijras could exert over the local population. Here we must point out again that the hijras and the people in them, and in constant movement between them, must have been few compared to the general population, who held various degrees of sympathy with them and loyalty towards them. Thus "the community of Mutarrifis" could range from networks of especially active Mutarrifis, to the community of the regional population who believed in their Mutarrifi doctrines or supported them.

59 Mentioned in Tabaqāt al-Zaydiyya al-kubrā, 2:1123.

6o Madelung quotes the Ghāyat al-amānī, which states that the Muțarrifiyya wanted in to hold back zakāt and revenue from endowments from al-Manșūr 'Abd Allāh b. Ḥamza. Madelung, "The Origins", 43 n. 85. This information indicates that there were awqā $f$ inside Muțarrifi territory, the control over which was valuable to them and to the imam. 'Ali Muhammad Zayd quotes the "Ajwibat masāill" stating that around 1215, the Muṭarrifiyya were forced to sell some of their lands and endowments (here: wașāya $)$ to the Ayyūbids and the imam criticized them for that. Zayd, Tayyārāt, 174. The "Ajwibat masāil" is edited in 'Abd al-'Ạṭī, al-Ṣirā' al-fikrī, 142-74. For the passage about the wașāyā, see ibid, 161. 
The 11th century is also the mature phase of the Mutarrifiyya. They are opposed by two strong Zaydi imams, first al-Mutawakkil Ahmad b. Sulaymān (r. 1138-1171), and later al-Manșūr 'Abd Allāh b. Ḥamza (r. 1187-1217). AlMutawakkil was contemporary with al-Lahjī, and perhaps his main opponent. In his later career Al-Mutawakkil was not recognized as imam by al-Lahjī and his fellow Mutarrifis. He is a typical representative of the imam-centred vision of community, which remained quite stable throughout the whole period under scrutiny. Not only did he claim to control the collection and usage of $z a k a \bar{t}$ like al-Hādī, but he and his court scholar al-Qāọī 'Abd al-Jabbār also claimed the right to claim support for holy war, jihäd, and that this was in addition to the right to demand zakāt. This support tax was called ma'üna and legitimized by "necessity" and by quoting stories of al-Hādī demanding a quarter of the property of the people of Sanaa in order to finance the defences. ${ }^{61}$ The imam al-Manșūr 'Abd Allāh b. Hamza (r. 1187-1217) also demanded control over the zakät, but he went even further and declared the Muțarrifis to be heretical, confiscated their lands and destroyed their main hijra by military force. The latter episode and the process leading up to it cannot be treated here as it is outside the scope of this chapter. However, is should be mentioned that from now on hijras were no longer Muțarrifi and after this point in history a hijra mainly refers to a village of $a s h r a \bar{f}$ or sāda population.

\section{Conclusion}

As we have seen, the ideas, practices and institutions related to the hijra in the period AD 900-1200 in Zaydi medieval highland Yemen changed a great deal. Likewise, the importance of the role of zakāt and management of surplus, wealth and welfare varied greatly from time to time, from place to place and from sect to sect, and the ideals differed from the pragmatic rules. I have tried to sketch out some of the most basic differences and dynamics related to this over the centuries, but needless to say is this chapter only a vague beginning of a portrait of a much finer detail. In this chapter I have shown three source texts, or cases: first, al-Hādì's justification of not spending zakāt income on the poor, and the two others demonstrating how zakāt and welfare was used in a non-imamic-centred vision of community promoted by the Mutarrifiyya. The first of these two latter cases shows how zakāt could be collected and spent locally, and the last show how welfare could be organized inside an enclave of learning as an institution, arguably similar to a gompa or a monastery.

61 Al-Thaqafī, Sìrat al-Imām Aḥmad b. Sulaymān, 298-305 and especially 302-03. 
The early ashräf-dominated hijras were a very different phenomenon compared to the later Muțarrifi hijras, just as the imam-centred vision of community was very different from that produced and upheld in local networks of pious Muțarrifi individuals.

In this chapter, I have not sought to prove the relative importance of welfare in Zaydi visions of community, but rather how visions of welfare and its role for the community was contested among Zaydis at the time. The enclaves of learning (hijras) were both products of such visions, but also the frames in which such visions could be formulated, discussed, codified, and learned. Welfare was important for the inhabitants, but the exact nature of the causal relation between visions, practice, and institutions cannot be established from the few sources analysed here. Our sources from this period are highly situated and biased and the deliberate contrasting of competing visions allows us to better see the relation between the ideal and pragmatic versions of their visions, and it allows us to carry out (at least to start) source criticism.

The visions of community discussed in this chapter can been seen in at least four distinct, yet interconnected levels, as also mentioned in the introduction to this section of this volume. First, individual "enclaves of learning": this level of community refers to the community inside single, individual enclaves, for example Hijrat Waqash. It is characterized by daily face-to-face interaction and common practices and rituals. The "outsiders" are the tribal surroundings around the enclave and other enclaves located at a distance. Individual hijras had protection agreements with surrounding tribes (tahjir, juwāra, jiwār). ${ }^{62}$ Second, sub-sects: this level refers to networks and sects ${ }^{63}$ within Zaydism in Yemen in the medieval period, for example the Mutarrifiyya. Outsiders are the other competing Zaydi sects, elites and networks, such as various ashräf clans (Hādawiyya, Qāsimiyya, Ḥamzawiyya), or the more theologically defined counterpart to the Mutarrifiyya, the Mukhtari'a. ${ }^{64}$ The landscape of Zaydi sects changes much during this period, as we have seen. In short, this level

62 For the protection agreement regarding ('aqd jiwār) of foundation of Hijrat Waqash see Madelung, "Origins", 32; al-Lahjīi, "Akhbār al-Zaydiyya", 78.

63 A practical comparative question is to what extent the word "sect" is useful. In contemporary popular English it has a negative meaning. What do we call a religious subcommunity in a generic term? And how can we differentiate between a monastic order and a religious sect? Alternative terms like "networks" or "movements" have other additional connotations. The degree of institutionalization and forms of hierarchy would be important to clarify. See especially the chapter by O'Riain in this volume. Some terms used in the Yemeni sources to indicate religious sub-groups are firqa, țäifa and madhhab.

64 The Mukhtaria consisted of various scholars, among them several court scholars of powerful Muțarrifi-hostile imams who especially attacked the natural causation theory of the 
comprises several "enclaves of learning" coming together in a network, sharing fundamental doctrines and sharing ideas and practices of welfare, rituals and religion. Third, the (Yemeni) Zaydi community: this level refers to the general Zaydi cause in Yemen. The real, imagined or invoked enemies are other Islamic sects, such as the Sunnis and Isma'ilis, who especially at times of war were portrayed as non-believers and outside the community. The Zaydis cultivated a distinct form of Islamic doctrine both in theology and law. The doctrinal differences were presumably not always obvious to commoners, but in cases where this level was invoked among them, more simplified slogans could be used. For many commoners, the most practical difference would be to whom one had to pay taxes in times of peace and whom one would be forced to side with in times of war. The fact that certain tribes and tribal elites in the border areas could change sides several times does not mean that commoners changed doctrines overnight. Fourth, the wider Muslim community: this is possibly a fourth level, at least commonly seen invoked in the sources-the umma, the totality of Muslim community, similar to jamāa in the chapter by Rudiger Lohlker and in the response to the chapter of Gerda Heydemann. The outsiders would be people of other religions, such as the Jews, or groups with a "deficiency" of religion altogether, such as the tribal population that religious authors at times describe as un-Islamic or mention when describing al-Hādì's quest to spread Islam among the tribes. To scientifically represent the community of the umma or other ideal communities is problematic, since it exists only at a highly ideal level, as a vision; usually, there is no corresponding social group in reality matching the vision, yet the vision is constantly invoked and claimed in a wide variety of ways. Discourse invoking this level of community is also used parallel to, and mixed with, the second and third level described above, for example when declaring other Zaydi sects to be heretical and therefore not part of "the umma" and outside of dār al-Isläm ("territory of Islam", where individuals have rights as Muslims according to Islamic law, as opposed to dār al-harb, territory of war, or dār al-fisq "territory of immorality", invoked to confiscate land belonging to recalcitrant Zaydis). ${ }^{65}$

This summary of four levels reminds us that visions of community are ideas and notions that are constantly invoked and used in rather creative and ambiguous ways, and therefore we have to be careful in not representing them as

Mutarrifiyya. The name comes from the theological concept $i k h t i r \bar{a}$, creation ex nihilo. Madelung, "Muțarrifiyya", Thiele, Theologie; Zayd, Tayyārāt.

65 For the legal concept of dār al-fisq located between dār al-Islām and dār al-kufr, see al-Imām al-Manșūr 'Abd Allāh b. Ḥamza, al-Majmū al-Manșūrī, 2:64-67. 
fixed essences, and further, that we must always look at the exact context in which they are used, grounding the visions in the social and political context where they are invoked, transmitted, and used. To claim that the umma existed, as a vision of community, means in a minimal historical sense that it existed as an idea (re)presented in a text. What concerns us, however, is how this vision was used on various levels and to which extent the agency behind these claims resulted in an effective community, and further, how this effect was observed, commented upon, and resisted by others. We need ideal types of these visions of community and to represent these as models. However, the phenomena located on the borders of these ideal types, where visions are unclear and contested, are more yielding study objects if we want to understand the dynamic and the agency that we can see in our sources.

\section{Bibliography}

'Abd Allāh b. Ḥamza, al-Imām al-Manșūr Bỉ'llāh, Al-Majmūu al-Manșūrī (al-Qism al-thānī) Majmūe rasāil al-Imām al-Manșūr Bi-llāh 'Abd Allāh b. Hamza, ed. 'Abd al-Salām b. 'Abbās al-Wajīh (Sanaa, 2001).

'Abd al-Ghanī Maḥmūd 'Abd al-Āṭī, al-Ṣirā' al-fikrī fí l-Yaman bayna al-Zaydìyya wa-lMuțarrifiyya: Dirāsa wa-nușūṣ (Cairo, 2002).

'Alī b Muḥammad b. 'Ubayd Allāh al-'Abbāsī al-'Alawī, Sưrat Hādī ilā al-Haqq Yahyā b. al-Husayn [Biography of al-Hādīi ilā al-Ḥaqq Yahyā b. al-Ḥusayn], ed. Suhayl Zakkār (Beirut, 1981).

Cornelis van Arendonk, De Opkomst van het Zaidietische imamaat in Yemen (Leiden, 1919).

Michael Cook, Commanding Right and Forbidding Wrong in Islamic Thought (Cambridge, 2010).

Patricia Crone, God's Rule: Government and Islam: Six Centuries of Medieval Islamic Political Thought (New York, 2005).

Paul Dresch, Tribes, Government, and History in Yemen (Oxford, 1989).

David Thomas Gochenour, "The Penetration of Zaydi Islam into Early Medieval Yemen", (PhD diss, Harvard University, 1984a).

David Thomas Gochenour, "Towards a Sociology of the Islamisation of Yemen", in Contemporary Yemen: Politics and Historical Background, ed. Brian R. Pridham (New York, 1984b), 1-19.

Johann Heiss, "Tribale Selbstorganisation und Konfliktreglung: Der Norden des Jemen zur Zeit des ersten Imams (10. Jahrhundert)" (unpublished PhD diss., University of Vienna, 1998). 
Eirik Hovden, "Flowers in fiqh and Constructions of Validity: Practices and Norms in Yemeni Foundations of Forever Flowing Charity" (Unpublished PhD diss., University of Bergen, 2012).

Ibrāhīm b. al-Qāsim b. al-Mu'ayyad, Ṭabaqāt al-Zaydiyya al-kubrā; al-Qism al-thālith wa-yusamma: Bulūgh al-marām ilā ma'rifat al-isnād, ed. 'Abd al-Salām b. 'Abbās al-Wajīh (Sanaa, 2001).

Hugh Kennedy, "The Ribāt in the Early Islamic World", in Western Monasticism Ante Litteram, eds. Hendrik Day and Elizabeth Fentress (Turnhout, 2011), 161-75.

Al-Lahjīi, Abū al-Ghamr Musallam b. Muhammad b. Jaffar, "Akhbār al-Zaydiyya min ahl al-bayt 'alayhim al-salām wa-shī'atihim bi-al-Yaman”, MS Jāmi'at al-Imām Muḥammad b. Sa'ūd al-Islāmiyya, MS no. 2449.

Wilferd Madelung, Der Imam al-Qāsim ibn Ibrāhìm und die Glaubenslehre der Zaiditen, Studien zur Sprache, Geschichte und Kultur des islamischen Orients, Neue Folge Band 1. (Berlin, 1965).

Wilferd Madelung, "Land Ownership and Land Tax in Northern Yemen and Najrān:

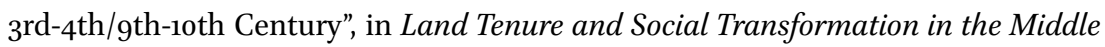
East, ed. Tarif Khalidi (Beirut, 1981), 189-207. Republished in id., Religious and Ethnic Movements in Medieval Islam (Farnham, Brooksfield, 1992).

Wilferd Madelung, "Has the Hijra Come to an End?" Revue des études islamiques (1984), 225-37. Republished in id., Religious and Ethnic Movements in Medieval Islam (Farnham, Brooksfield, 1992).

Wilferd Madelung, "Al-Hamdānīs Description of Northern Yemen in the Light of Chronicles of the 4 th/1oth and 5th/11th Centuries", in Al-Hamdāni a Great Yemeni Scholar: Studies on the Occasion of his Milennial Anniversary, ed. Yusuf Mohammad Abdallah (Sanaa, 1986), 129-37. Republished in id., Religious and Ethnic Movements in Medieval Islam (Farnham, Brooksfield, 1992).

Wilferd Madelung, "The origins of the Yemenite Hijra", in Arabicus Felix: Luminosus Brittanicus: Essays in Honour of A.F.L. Beeston on his Eightieth Birthday, ed. Alan Jones (Reading, 1991), 25-44. Republished in id., Religious and Ethnic Movements in Medieval Islam (Farnham, Brooksfield, 1992).

Wilferd Madelung, "Muțarrifiyya", in Encyclopaedia of Islam, new ed., eds. Peri J. Bearman, Thierry Bianquis, Clifford Edmund Bosworth, Emeri J. van Donzel and Wolfhart P. Heinrichs (Leiden, 1960-2004), 7:772-73.

Gerd R Puin, "The Yemeni Hijrah Concept of Tribal Protection", in Land Tenure and Social Transformation in the Middle East, ed. Tarif Khalidi (Beirut, 1984), 483-94.

Al-Raba'̄ī, Mufarriḥ b. Aḥmad, Sìrat al-amīrayn al-jalīlayn al-sharīfayn al-fādilayn

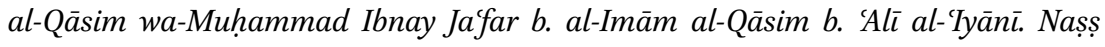
tārīkhī Yaman̄̄ min al-qarn al-khāmis al-hïrī, eds. Riḍwān al-Sayyid and Abd al-Ghanī Maḥmūd 'Abd al-'Āṭī (Beirut, 1993). 
Armando Salvatore and Mark LeVine, "Chapter 1: Socio-Religious Movements and the Transformation of 'Common Sense' into a Politics of 'Common Good”, in Religion, Social Practice, and Contested Hegemonies: Reconstructing the Public Sphere in Muslim Majority Societies, eds. Armando Salvatore and Mark LeVine (New York, 2005), 29-56.

Robert Bertram Serjeant, "Chapter 5: Șan‘ā’ the protected Hijra”, in Șan'ā’ An Arabian Islamic City, eds. Robert Bertram Serjeant and Ronald Lewcock (London, 1983), 39-43.

Robert W Stookey, Yemen: The Politics of the Yemen Arab Republic, Westview Special Studies on the Middle East (Boulder, 1978).

Al-Thaqafī, Sulaymān b. Yaḥyā, Sìrat al-Imām Aḥmad b. Sulaymān 535-566 H, ed. 'Abd al-Ghanī Maḥmūd 'Abd al-Āṭ̣̂ (Giza, 2002).

Jan Thiele, Theologie in der jemenitischen Zaydiyya: die naturphilosophischen Überlegungen des al-Hasan ar-Rașșās (Leiden, 2013).

Montgomery W. Watt, "Hidjra", in Encyclopaedia of Islam, new ed., eds. Peri J. Bearman, Thierry Bianquis, Clifford Edmund Bosworth, Emeri J. van Donzel and Wolfhart P. Heinrichs (Leiden, 1960-2004), 3:366-67.

Yaḥyā b. al-Ḥusayn, al-Hādī ilā al-Ḥaqq, al-Majmū'a al-Fākhira:Majmū' kutub wa-rasā̇il al-Imām al-Hādī ilà al-Haqq Yahyā b. al-Husayn (Sanaa, 2000).

Yahyyā b. al-Ḥusayn, Kitāb al-Ạ̣kām fì al-ḥalāl wa al-ḥarām, paginated file downloaded from http://www.anazydi.com, last retrieved 10.12.2013.

'Alī Muhammad Zayd, Tayyārāt mu'tazilat al-Yaman fì l-qarn al-sādis al-hïrī (Sanaa, 1997).

Aron Zysow, "Zakāt", in Encyclopaedia of Islam, new ed., eds. Peri J. Bearman, Thierry Bianquis, Clifford Edmund Bosworth, Emeri J. van Donzel and Wolfhart P. Heinrichs (Leiden, 1960-2004) 6:406-22.

Aron Zysow, "The obligation to obey God's commands", in The Law Applied, eds. Peri Bearman, Wolfhart Heinrichs and Bernhard G. Weiss (London, New York, 2008), 397-421. 